\begin{tabular}{|c|c|}
\hline$\$$ sciendo & 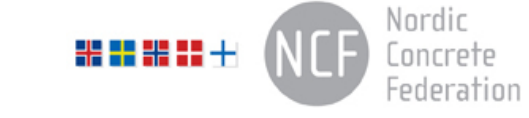 \\
\hline $\begin{array}{l}\text { (C) Article authors. This is an open access article distributed under } \\
\text { the Creative Commons Attribution-NonCommercial-NoDerivs } \\
\text { licens. (http://creaticecommons.org/licenses/by.nc-nd/3.0/). }\end{array}$ & $\begin{array}{l}\text { ISSN online } 2545-2819 \\
\text { ISSN print } \quad 0800-6377\end{array}$ \\
\hline DOI: $10.2478 /$ ncr-2021-0015 & $\begin{array}{r}\text { Received: Sept. 26, } 2021 \\
\text { Revision received: Dec. 19, } 2021 \\
\text { Accepted: Dec. 20, } 2021\end{array}$ \\
\hline
\end{tabular}

\title{
Visible Corrosion Damage in Carbonated Reinforced Concrete
}

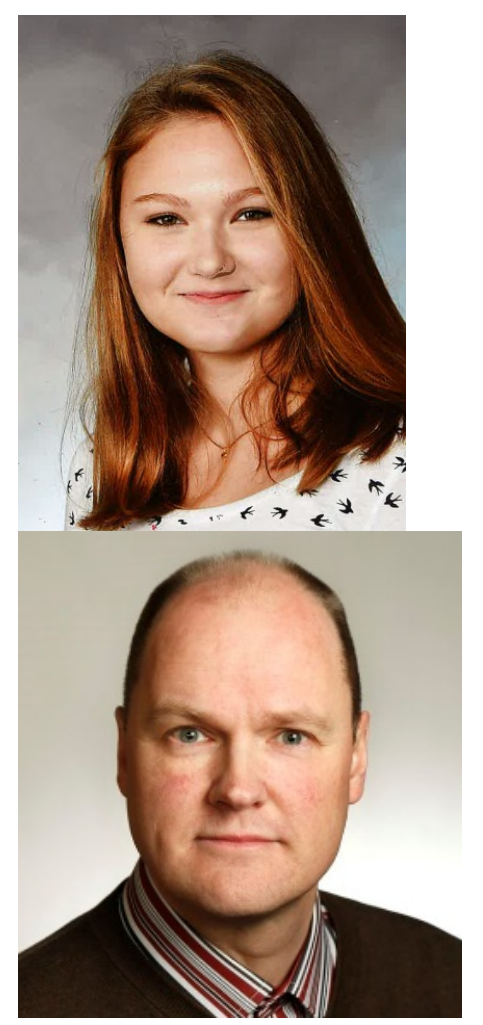

\author{
Alina Lahdensivu \\ MSc student \\ Tampere University \\ alina.lahdensivu@tuni.fi
}

Jukka Lahdensivu, DSc

Adjunct Professor

Tampere University

jukka.lahdensivu@,tuni.fi

\begin{abstract}
This study discusses visible corrosion damage due to carbonation in concrete balconies and facades. The focus of the study was to find out how the age of the structure, cover depth of concrete, carbonation coefficient, capillarity of concrete and the climate affect visible corrosion damage. The research data consist of condition investigation reports of existing concrete balconies and facades built between 1948 and 1996.
\end{abstract}

Balcony slabs and brushed painted facades were the most prone to visible corrosion damage. None of the researched panels met the required minimum cover depth of reinforcement even at the time of construction. However, most of the visible damage on the database was localized damage and there was not much visible corrosion damage. The carbonation coefficient of balconies was higher 
than the carbonation coefficient of facades. Brushed painted facade panels had clearly higher carbonation coefficient than other facade panels. The carbonation coefficient was considerably lower on white concrete panels compared to other panel types.

When capillarity of concrete raises, the carbonation rate of concrete increases slightly. However, no correlation can be seen. The capillarity of concrete and the carbonation rate of concrete had a major range.

Key words: Corrosion, carbonation, capillarity, reinforcement, visible damage, field study.

1.

\section{INTRODUCTION}

1.1

General

The concrete industry, together with the steel industry, plays a key role in reducing greenhouse gas emissions in the climate. Cement production causes up to $1.3 \%$ of all greenhouse gas emissions in Finland [1]. Globally, cement production causes about $5 \%$ of all greenhouse gas emissions [2]. To reduce emissions, concrete is increasingly using other binders mixed with Portland cement. The most common supplementary cementing materials are silica, fly ash and blast furnace slag. Cements with large amount of those binders are faster carbonating concrete, containing smaller amount of carbonating calcium hydroxide $\left(\mathrm{Ca}(\mathrm{OH})_{2}\right)$ in concrete. This might lead to faster corrosion damage than in concrete using pure Portland cement [3].

In Finland carbonation induced corrosion damage together with freeze-thaw damage in non-airentrained concrete facades and balconies are the main reasons for repair in existing block of flats [4]. Observations related to reinforcement corrosion in carbonated concrete from 21 concrete buildings in Japan tell us that approximately $30 \%$ showed no corrosion and approximately 405 showed a few rust spots on the surface of steel bars. In Switzerland 195 local inspections in more than 40 concrete structures showed $10 \%$ absence of reinforcement corrosion in carbonated concrete and approximately $45 \%$ a few rust spots on the surface of steel bars. Only about 10-15 $\%$ of the corrosion damage of reinforcements was relevant [5].

This study discusses visible corrosion damage due to carbonation in concrete balconies and facades in Finland. The focus of the study was to find out how the age of the structure, cover depth of concrete, carbonation coefficient, capillarity of concrete and the climate affect visible corrosion damage.

\subsection{Carbonation of concrete}

In concrete facade and balcony elements, the reinforcements are inside the concrete, which is why the reinforcements have physical protection against the factors that affect corrosion. Together with physical protection, reinforcement is protected chemically, too. The pore water of the concrete has a high alkalinity, which forms an oxide layer on the surface of the reinforcement. This oxide layer protects chemically the reinforcement from corrosion [6]. Corrosion of reinforcements is a chemical electrolytic reaction in which the reinforcement acts regionally as both a cathode and an anode. 
The hydration reaction of cement generates small quantities of readily soluble alkali hydroxides sodium hydroxide $(\mathrm{NaOH})$ and potassium hydroxide $(\mathrm{KOH})$, and a large proportion of calcium hydroxide $\left(\mathrm{Ca}(\mathrm{OH})_{2}\right)$. Due to the high concentration of hydroxides, the pore water is highly alkaline, which protects the reinforcements as long as the conditions are alkaline [7,8]. Corrosion of reinforcements begins when the alkalinity of the concrete has decreased to a suitable level due to the carbonation of the concrete [6]. In addition to the $\mathrm{pH}$ of the concrete, it has been found that carbonation of concrete reduces its porosity and increases the compressive strength of the concrete as well as the surface hardness [9].

Carbonation of concrete is a chemical reaction between carbon dioxide and the hydration products of cement in the air and can be described with highly simplified Equation 1 [7]. The reactants are generally calcium silicate hydrate, calcium hydroxide and various calcium aluminate or ferroaluminate hydroxides. Carbon dioxide dissolves in the pore water and forms the carbonic acid of the hydroxides, which neutralizes the basicity of the pore water by forming salts. As a result of hydration, the concrete contains more calcium hydroxide than it can dissolve in the pore water. Therefore, the concrete retains a high $\mathrm{pH}$ during carbonation. $[9,10,11]$

$$
\mathrm{Ca}(\mathrm{OH})_{2}+\mathrm{CO}_{2} \rightarrow \mathrm{CaCO}_{3}+\mathrm{H}_{2} \mathrm{O}
$$

Simplified, when the concrete no longer contains calcium hydroxide that could dissolve in the pore water, carbonation penetrates deeper into the concrete. Concrete carbonates only when there is enough pore water to dissolve the hydroxides. According to Figure 1, carbonation occurs most in the exposure classes XC3 and $\mathrm{XC4}$, as the humidity is favourable [9].

\section{Relative carbonation of concrete and corrosion of renforcement}

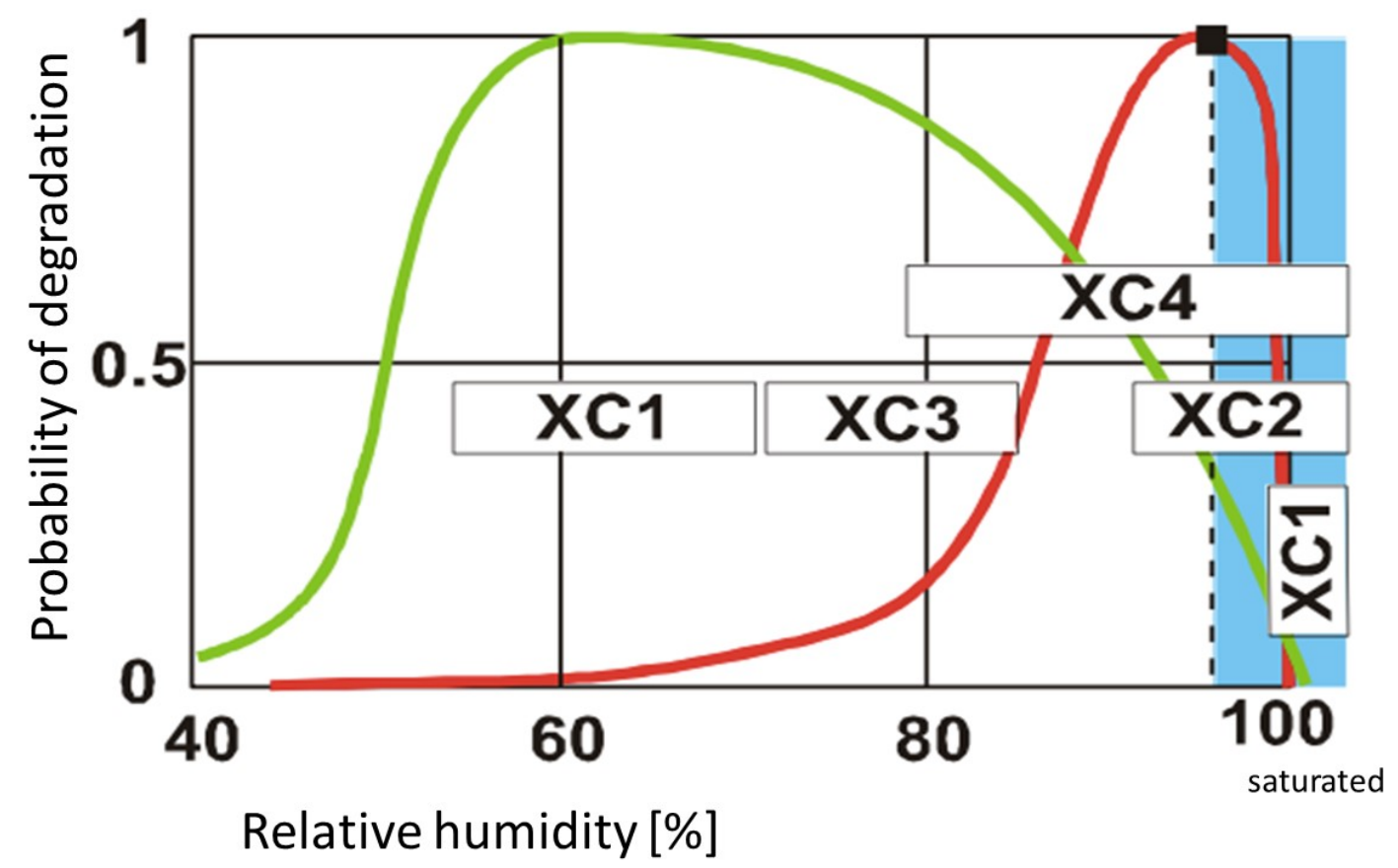

Figure 1 -Effect of relative humidity of concrete on carbonation rate of concrete and corrosion rate of reinforcement $[12,13]$. 
The water-cement ratio of concrete describes the density of the concrete and the amount of cement, which are essential when considering carbonation. In dense concrete, the penetration of carbon dioxide into the concrete pore network is slow, because under the same humidity conditions, dense concrete has more water-saturated pores than sparse concrete. Carbon dioxide cannot penetrate the water-saturated pores or the diffusion of carbon dioxide in the water-saturated pore network is so slow that carbonation does not occur. The amount of cement or more precisely the amount of calcium hydroxide $\left(\mathrm{Ca}(\mathrm{OH})_{2}\right)$ affects the rate of carbonation of the concrete. Therefore, the cement type has an effect on the carbonation rate of concrete. The low watercement ratio slows down the rate of carbonation because it makes the concrete denser and has fewer capillary pores in the pore structure of the concrete.

\subsection{Corrosion of reinforcement}

Corrosion of reinforcements is a chemical electrolytic reaction in which reinforcing steel acts as both a cathode and an anode. When the carbonation front reaches the steel, the protective oxide film disappears in that part and the steel acts as an anode in the corrosion reaction. In other parts of reinforcement, where the steel still has an oxide film, the steel acts as a cathode. Corrosion is typically described by the following three Equations: anode reaction (2), cathode reaction (3), and total corrosion reaction (4), in which steels are assumed to be pure iron.

$$
\begin{aligned}
& \mathrm{Fe} \rightarrow \mathrm{Fe}^{2+}+2 \mathrm{e}^{-} \\
& 2 \mathrm{e}^{-}+\mathrm{H}_{2} \mathrm{O}+1 / 2 \mathrm{O}_{2} \rightarrow 2 \mathrm{OH}^{-} \\
& \mathrm{Fe}+\mathrm{H}_{2} \mathrm{O}+1 / 2 \mathrm{O}_{2} \rightarrow \mathrm{Fe}(\mathrm{OH})_{2}
\end{aligned}
$$

The electrons generated in the corrosion reaction do not remain free in the pore water as the charge is transferred to ions at the steel surface. The hydroxide ions $\left(\mathrm{OH}^{-}\right)$released in the anode reaction increase the alkalinity of the pore water and strengthen the oxide layer of steels in the cathode regions. Compounds resulting from the cathode and anode reaction promote rusting of reinforcements. Iron ions react with other compounds in pore water forming rust [10].

The total reaction 4 produces iron (II) hydroxide $\left(\mathrm{Fe}(\mathrm{OH})_{2}\right)$, which reacts with the available oxygen and water to forming rust. These reaction products include iron (III) hydroxide $\left(\mathrm{Fe}(\mathrm{OH})_{3}\right)$, hydrated iron oxide $\left(\mathrm{Fe}(\mathrm{OH})_{3} \cdot 3 \mathrm{H}_{2} \mathrm{O}\right)$, magnetite $\left(\mathrm{Fe}_{3} \mathrm{O}_{4}\right)$, and hematite $\left(\alpha-\mathrm{Fe}_{2} \mathrm{O}_{3}\right)$. Depending on the availability of oxygen and water, different reaction products are generated in different amounts. Each reaction product has its own densities, so the same amount of steel can give a different amount of different reaction products that expand differently. Expansion of the reaction products eventually causes damage to the concrete when the pressure caused by the expansion exceeds the tensile strength of the concrete $[10,11]$.

From Figure 1 it can be seen the dependence of the corrosion of reinforcement and the rate of carbonation of concrete on relative humidity in different exposure classes. In the exposure classes $\mathrm{XC} 3$ and $\mathrm{XC} 4$, the carbonation rate slows down all the time as the corrosion rate increases. In exposure class $\mathrm{XC} 3$, the relative humidity is about 70-85\%. At $80 \%$ humidity, the corrosion rate starts to increase sharply. Exposure class XC4 as a whole is in the area of rapid corrosion. The corrosion rate also peaks in the exposure class $\mathrm{XC} 4$ as the relative humidity approaches saturation. However, the peak corrosion rate is not usually observed [5]. It can be concluded that corrosion 
damage will appear more probably in exposure class XC4 if carbonated concrete will get wet for some reason, e.g. malfunction of water drainage of balcony slab [4, 12, 13].

\section{2.}

\section{CONCRETE FACADES AND BALCONIES IN FINLAND}

Concrete facades and balconies have been prefabricated elements in Finland since the late 1960's. Facade panels are sandwich-panels made up of two relatively thin reinforced concrete layers connected to each other by steel trusses. Typical properties of Finnish prefabricated facades and balconies are presented in Table 1. The thermal insulation between the layers is most often mineral wool of 60 to $220 \mathrm{~mm}$ nominal thickness depending on the building regulations in force at the time of design and construction, see Figure 2.

Table 1 - Typical dimensions, reinforcement and surface treatment of Finnish prefabricated facades and balconies.

\begin{tabular}{|c|c|c|c|}
\hline Element & Dimensions & Reinforcement & Surface treatment \\
\hline $\begin{array}{l}\text { Facade } \\
\text { sandwich } \\
\text { panel }\end{array}$ & $\begin{array}{l}\text { Outer layer } 40- \\
85 \mathrm{~mm} \\
\text { Inner layer } 150 \mathrm{~mm} \\
\text { (bearing) or } 80 \mathrm{~mm} \\
\text { (non-bearing) }\end{array}$ & $\begin{array}{l}\text { Outer layer (non-bearing): } \\
\text { Mesh } 3-4 \mathrm{~mm} \text { with } 150 \mathrm{~mm} \text { spacing, } \\
\text { Edge bars } 6 \text { or } 8 \mathrm{~mm} \text {, } \\
\text { Trusses combining outer and inner layer } \\
\text { spacing } 600 \mathrm{~mm} \text {, } \\
\text { Lifting straps }\end{array}$ & $\begin{array}{l}\text { Typical surface varies during } \\
\text { architectural fashion. The most } \\
\text { typical surfaces are: } \\
\text { Exposed aggregate concrete } \\
\text { Brushed and painted concrete } \\
\text { Ceramic or brick tile on surface }\end{array}$ \\
\hline $\begin{array}{l}\text { Balcony } \\
\text { slab }\end{array}$ & $\begin{array}{l}\text { Thickness 140- } \\
\text { 200mm (sloped } \\
\text { upper surface) }\end{array}$ & $\begin{array}{l}\text { Lower section bearing reinforcement: } \\
10 \text { or } 12 \mathrm{~mm} \text { spacing } 100-150 \mathrm{~mm} \text {, } \\
\text { Upper section: } \\
\text { Tie rods, auxiliary reinforcement, lifting } \\
\text { straps }\end{array}$ & $\begin{array}{l}\text { Sloped upper surface with } \\
\text { painting. } \\
\text { Usually no waterproofing layer. }\end{array}$ \\
\hline $\begin{array}{l}\text { Balcony } \\
\text { side wall }\end{array}$ & $\begin{array}{l}\text { Thickness } \\
180 \mathrm{~mm}\end{array}$ & $\begin{array}{l}\text { Edge bars } 10 \text { or } 12 \mathrm{~mm} \\
\text { Lifting straps }\end{array}$ & $\begin{array}{l}\text { Typically plain concrete with } \\
\text { painting }\end{array}$ \\
\hline $\begin{array}{l}\text { Balcony } \\
\text { parapet }\end{array}$ & $\begin{array}{l}\text { Thickness } \\
85 \mathrm{~mm}\end{array}$ & $\begin{array}{l}6 \text { or } 8 \mathrm{~mm} \text { reinforcement spacing } 150 \mathrm{~mm} \\
\text { near both surfaces }\end{array}$ & $\begin{array}{l}\text { Brushed or plain concrete with } \\
\text { painting }\end{array}$ \\
\hline
\end{tabular}
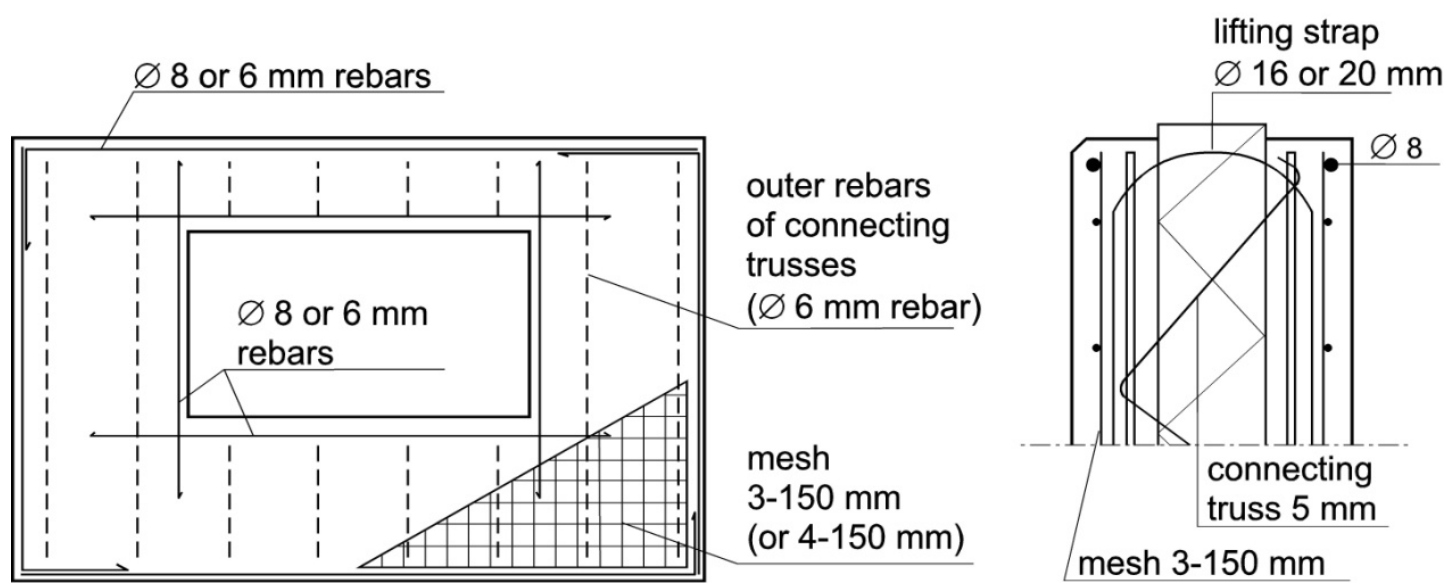

Figure 2-Typical reinforcement of outer layer of a concrete facade panel [14].

The water drainage systems of balconies vary a lot. Generally, the top surface of the slab has a slight slope, which leads rainwater to a drainpipe at the corner of the slab or outside through a spout pipe in the parapet. The water drainage system of some balconies consists of a gap between the slab and the parapet, which allows rainwater to exit the balcony. 
Facades, balcony parapets and side walls belong to exposure class XC3, i.e. moderately damp. Balcony slabs belong to exposure class XC4, i.e. periodic wetting and drying. This means that facades, balcony parapets and side walls are exposed to rain. Balcony slabs typically receive more rain stress than facades, so the top surfaces of the slabs are therefore in a different exposure class. In general, apartment balconies in new buildings have glazing, which reduces the rain stress on the interior surfaces of the balconies if they are caught in the rain. In exposure classes $\mathrm{XC} 3$ and $\mathrm{XC} 4$, the concrete cover thickness from the outer surface of the element to the surface of the first reinforcement must be at least $25 \mathrm{~mm}$ for a service life of 50 years and $30 \mathrm{~mm}$ for a service life of 100 years. In these exposure classes, the minimum amount of cement in concrete is $250 \mathrm{~kg} / \mathrm{m}^{3}$ $[15,16]$.

\section{3.}

\section{RESEARCH DATA AND METHODS}

The research data consist of condition investigation reports of concrete balconies and facades. The data have been collected by TUT between the years 2006 and 2009 [17]. Table 2 presents the sample size, average age of the structure at the time of condition investigation, standard deviation of average age and cover depth measurements of different element types. These samples have information about the age of the structure, carbonation depth, the type of visible corrosion damage, capillarity, and carbonation coefficient.

\begin{tabular}{|c|c|c|c|c|c|c|c|c|}
\hline \multirow[b]{2}{*}{ element } & \multicolumn{3}{|l|}{ Balconies } & \multicolumn{5}{|l|}{ Facades } \\
\hline & frame panel & slab panels & $\begin{array}{l}\text { parapet } \\
\text { panels }\end{array}$ & $\begin{array}{l}\text { brushed } \\
\text { painted } \\
\text { concrete }\end{array}$ & $\begin{array}{l}\text { ceramic tile } \\
\text { finishing }\end{array}$ & $\begin{array}{l}\text { exposed } \\
\text { aggregate }\end{array}$ & $\begin{array}{l}\text { brick tile } \\
\text { finishing }\end{array}$ & $\begin{array}{l}\text { white } \\
\text { concrete }\end{array}$ \\
\hline $\begin{array}{c}\text { number of } \\
\text { samples }\end{array}$ & 224 & 190 & 160 & 176 & 27 & 129 & 48 & 7 \\
\hline $\begin{array}{l}\text { average age at } \\
\text { the time of } \\
\text { condition } \\
\text { investigation } \\
\text { [a] }\end{array}$ & 24 & 25 & 25 & 26 & 24 & 22 & 18 & 22 \\
\hline $\begin{array}{c}\text { standard } \\
\text { deviation of } \\
\text { average age } \\
\text { [a] }\end{array}$ & 8 & 7 & 7 & 6 & 8 & 6 & 6 & 13 \\
\hline $\begin{array}{l}\text { number of } \\
\text { cover depth } \\
\text { measurements }\end{array}$ & 32405 & 55602 & 45707 & 39046 & 13207 & 61644 & 24766 & 6071 \\
\hline
\end{tabular}

The age of the structure is measured from the moment of completion to the moment the first visible corrosion damage is found on condition investigations. The average age and standard deviation of average age for balcony slab panels is $25 \pm 7$ years. The standard deviation for facade panels is between 6 and 13 years. Brick tile finished facades are younger compared to other facade panels since the average age for brick tile finished facades is 18 years and the standard deviation is only 6 years when the average age for other facades is 22-26 years and the standard deviation is 6-13 years. The standard deviation of white concrete facades is 13 years which is due to the small sample size $(\mathrm{n}=7)$.

The buildings have been divided into two groups by their location: costal area and inland area. The geographical division has been made with postal codes. Costal area includes all communes 
from Virolahti to Tornio that are located on the coast. Municipal division has since changed due to consolidation of municipalities. The municipal division is not as specific as in the doctoral thesis of Pakkala [18]. Pakkala has divided inland into three groups and the coastal area ends at the border of Uusi-Kaarlepyy [18]. The cover depth of concrete is compared between different element types and the carbonation coefficient is compared to capillarity. Carbonation coefficient is defined by measuring the carbonation depth of concrete and using Equation 5. The influence of climate to visible corrosion damage is investigated by comparing the environmental stress of inland structures and costal structures by researching the locations of buildings and points of compass of facades.

\section{RESULTS AND DISCUSSION}

The carbonation of concrete, cover depth of concrete and visible corrosion damage is investigated separately for balconies and facades. Balconies are investigated as three precast elements (slab, frame and parapet) and facades are investigated by their surface finishing. The sample sizes of some facades are not sufficient for statistical investigation $(\mathrm{n}<10)$. These defects are presented when needed.

During designing, every precast element has been established with a strength class which requirements the precast element should fulfil. The results of carbonation of concrete from the samples are compared to Figure 3. Currently the most typical strength classes for precast elements are $\mathrm{C} 20 / 25, \mathrm{C} 25 / 30$ and C30/37. The buildings are mainly completed in the 1980's, when facades were manufactured with strength class K25 or K30 (cubic strength [MPa]) concrete. Strength class K25 corresponds to Eurocode 2 strength class C20/25. Balconies were manufactured principally with strength class K30 concrete.

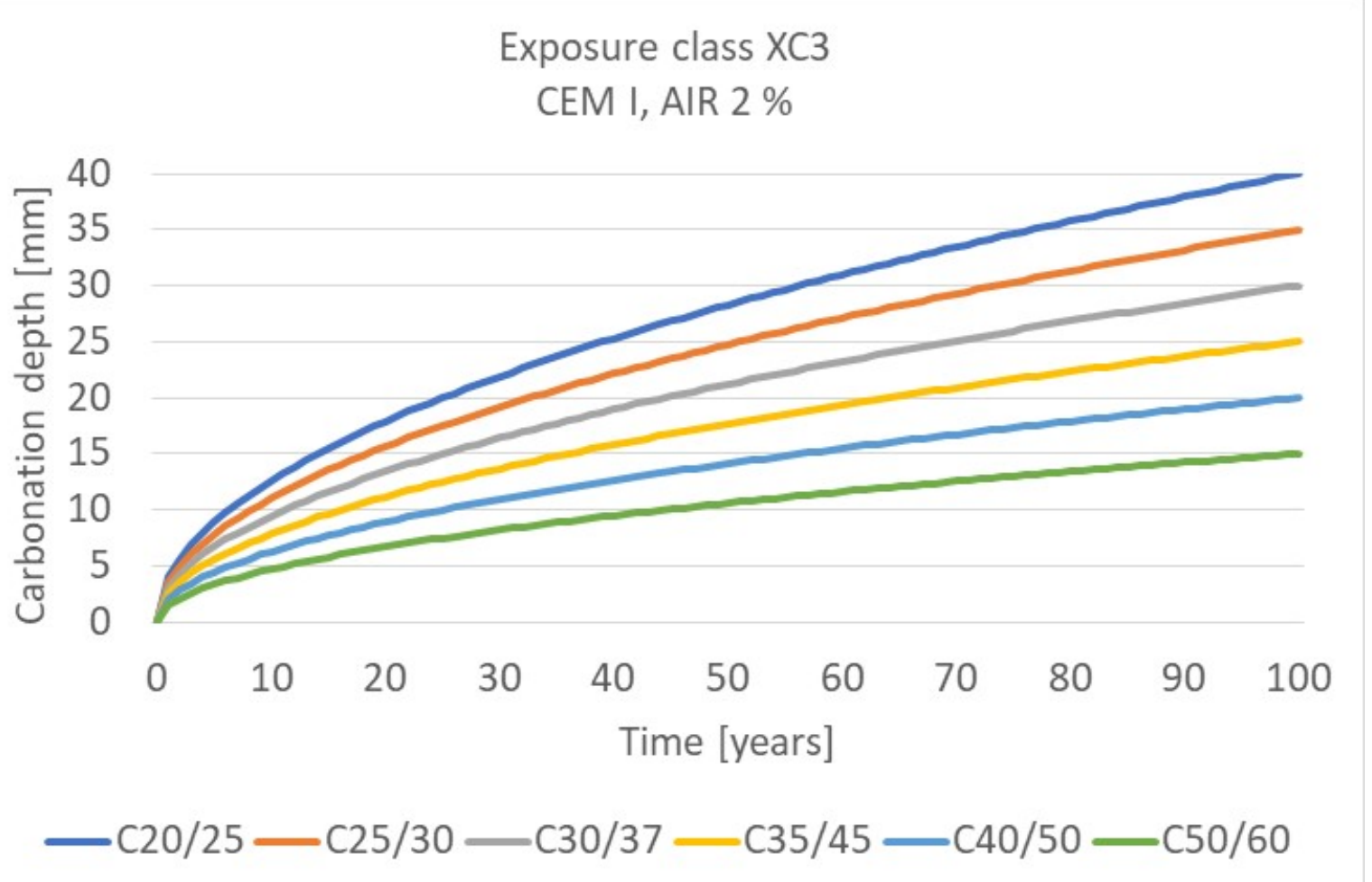

Figure 3 - Carbonation depth as a function of time in different strength classes according to publication BY68 [16]. 
The influence of strength class to service life of uncracked reinforced concrete structures can be estimated directly from Figure 3 [16]. The results from the research data are compared with Figure $3(\mathrm{C} 20 / 25, \mathrm{C} 25 / 30, \mathrm{C} 30 / 37)$ in the following chapters.

\subsection{Carbonation of concrete and capillarity}

The carbonation coefficient depicts the rate of carbonation in concrete in a certain time span, see Equation 5.

$$
k=x t^{-\frac{1}{2}}
$$

Equation (5) can be applied in practice by drawing comparable figures with Figure 3 from the data. Average carbonation depth was calculated for every precast element type.

\section{Carbonation in balconies}

Figure 4 has been drawn by applying the average carbonation depth to Equation (5). Figure 4 shows the calculated data for precast balcony elements.

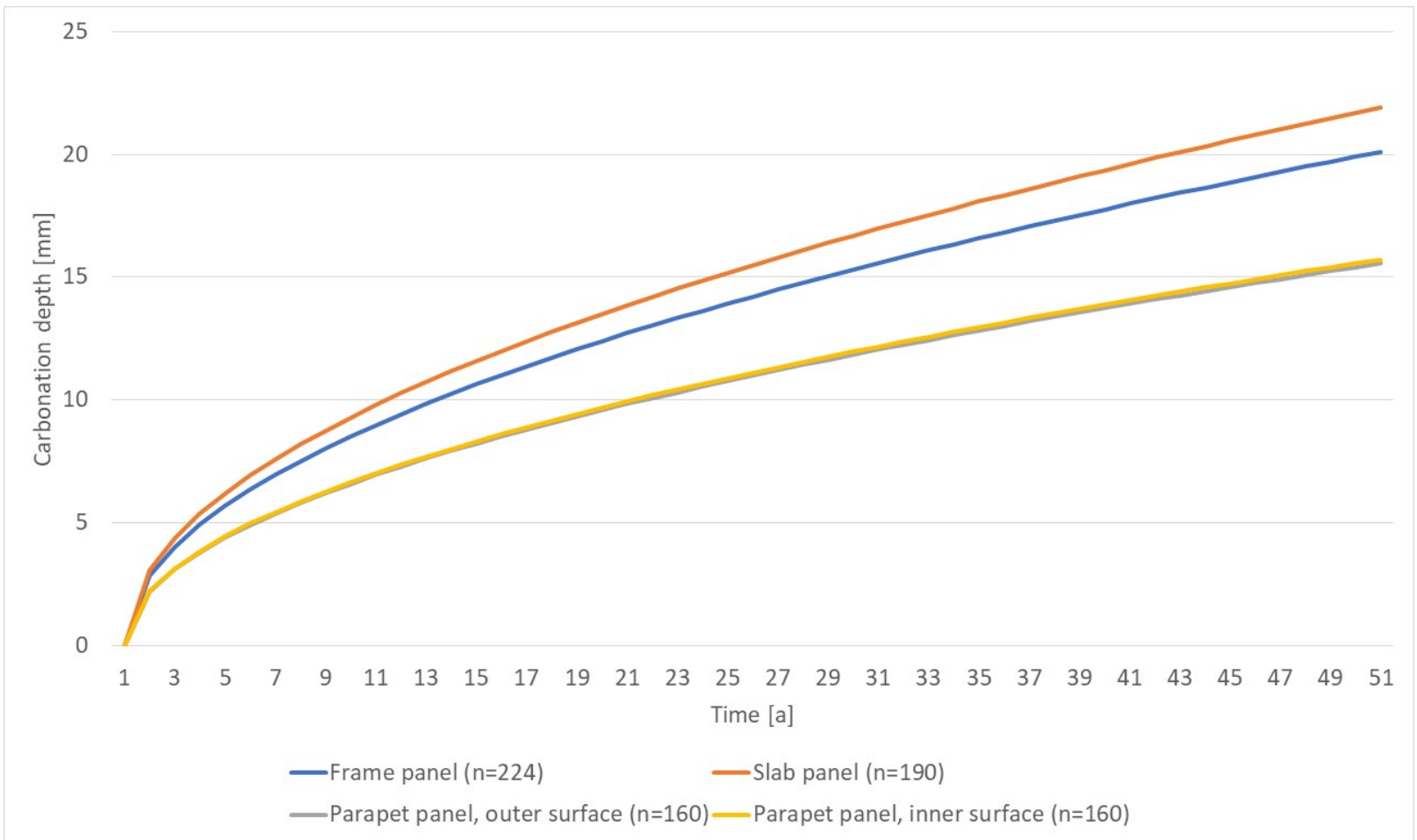

Figure 4-Carbonation depth as a function of time in different precast balcony element types.

Finnish national design guideline shows (Figure 3) rather pessimistic curves compared to collected data (Figure 4). In 25 years, the carbonation should advance to $28 \mathrm{~mm}$ in strength class C20/25 concrete, but the actual carbonation depth is $20 \mathrm{~mm}$ for frame panels, $22 \mathrm{~mm}$ for slab panels and $16 \mathrm{~mm}$ for parapet panels.

However, the carbonation coefficient has a wide deviation especially in precast balcony elements since they have areas that should not be exposed to rain. All the precast balcony elements follow Gaussian distribution; hence, the standard deviation includes $80 \%$ of all samples. Table 3 shows 
the average carbonation coefficient as well as the standard deviation of the carbonation coefficient of different balcony panels.

Table 3 - The average carbonation coefficient and standard deviation of the carbonation coefficient in different balcony panels.

\begin{tabular}{cccc}
\hline Element type & Exposure class & $\begin{array}{c}\text { The average carbonation } \\
\text { coefficient }\left[\mathrm{mm} / \mathrm{a}^{0,5}\right]\end{array}$ & $\begin{array}{c}\text { Standard deviation of } \\
\text { the carbonation } \\
\text { coefficient }\left[\mathrm{mm} / \mathrm{a}^{0,5}\right]\end{array}$ \\
\hline $\begin{array}{c}\text { Frame panel } \\
\text { Slab panel soffit }\end{array}$ & XC3 & 2.8 & 1.5 \\
$\begin{array}{c}\text { Parapet panel, outer } \\
\text { surface }\end{array}$ & $\mathrm{XC} 3$ & 3.1 & 1.2 \\
$\begin{array}{c}\text { Parapet panel, inner } \\
\text { surface }\end{array}$ & $\mathrm{XC} 3$ & 2.2 & 1.3 \\
\hline
\end{tabular}

The upper limit of the standard deviation for slab soffit reaches the carbonation depth of $21 \mathrm{~mm}$ in 25 years, which imitates the figure of strength class C20/25 (Figure 3). However, balcony slab panels are designed to be in strength class C25/30 that the upper limit of the standard deviation exceeds considerably. As time progresses, the gap between the calculated upper limit and strength class C20/25 [16] enlarges.

\section{Carbonation in facades}

Figure 5 has been drawn by applying the average carbonation depth to Equation (5). Figure 5 shows the calculated data for precast facade elements.

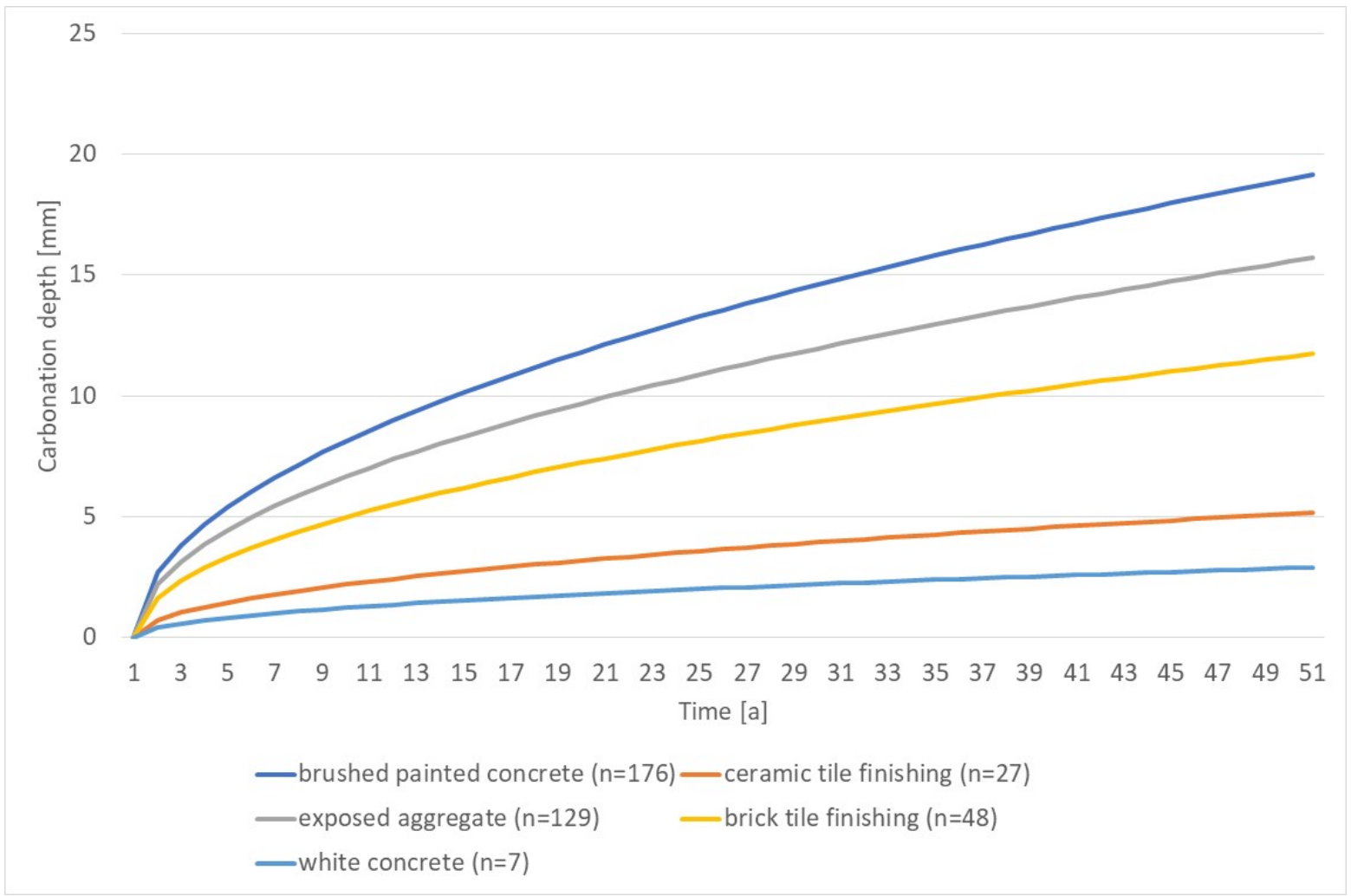

Figure 5 - Carbonation depth as a function of time in different precast facade element types.

The different surface types shown in Figure 5 have greatly different carbonation rates from each other. The carbonation proceeds the slowest in ceramic tile finished concrete and white concrete. 
The fastest carbonation occurs in brushed painted concrete. Exposed aggregate and brick tile finished concrete are in the middle of the extreme ends yet closer to the rate of brushed painted concrete.

In every element type the carbonation depth is much less than presented in national designing instructions. Even the fastest proceeding carbonation in brushed painted concrete reaches only a depth of $19 \mathrm{~mm}$ in 50 years, when in strength class C20/25 it should reach a depth of $28 \mathrm{~mm}$. On other facades' surface types, the carbonation depth is 3 to $16 \mathrm{~mm}$, which is greatly lower than the national instructions presume. The standard deviation is around the same with balcony elements excluding brick tile finishing concrete that has a standard deviation of $\pm 2.3 \mathrm{~mm}$ and white concrete with a standard deviation of $\pm 0.37 \mathrm{~mm}$.

Unlike in balconies, the carbonation coefficient does not follow Gaussian distribution in every facade finishing. Table 4 shows the average carbonation coefficient as well as the standard deviation of the carbonation coefficient of different facade panels. When the standard deviation of the carbonation coefficient is less than the average value, $80 \%$ of the samples fall between the higher and lower limit of the standard deviation.

Table 4 - The average carbonation coefficient and standard deviation of the carbonation coefficient in different facade panels.

\begin{tabular}{ccc}
\hline Element type & $\begin{array}{c}\text { The average carbonation } \\
\text { coefficient }\left[\mathrm{mm} / \mathrm{a}^{0,5}\right]\end{array}$ & $\begin{array}{c}\text { Standard deviation of the } \\
\text { carbonation coefficient } \\
{\left[\mathrm{mm} / \mathrm{a}^{0,5}\right]}\end{array}$ \\
\hline brushed painted facade & 2.7 & 1.0 \\
ceramic tile finishing facade & 0.7 & 1.4 \\
exposed aggregate facade & 2.2 & 1.1 \\
brick tile finishing facade & 1.7 & 2.3 \\
white concrete facade & 0.4 & 0.4 \\
\hline
\end{tabular}

\section{Capillarity of concrete in balconies}

Capillarity of concrete varies a lot between samples. The distribution of capillarity is rather similar in all balcony element types as can be seen on Figure 6 . Capillarity varies between $3.7 \mathrm{w}-\%$ and $10.1 \mathrm{w}-\%$. Capillarity of concrete is rising of water in capillary pores influenced by its surface tension. The porosity of concrete and water to cement ratio can be determined using capillarity. 


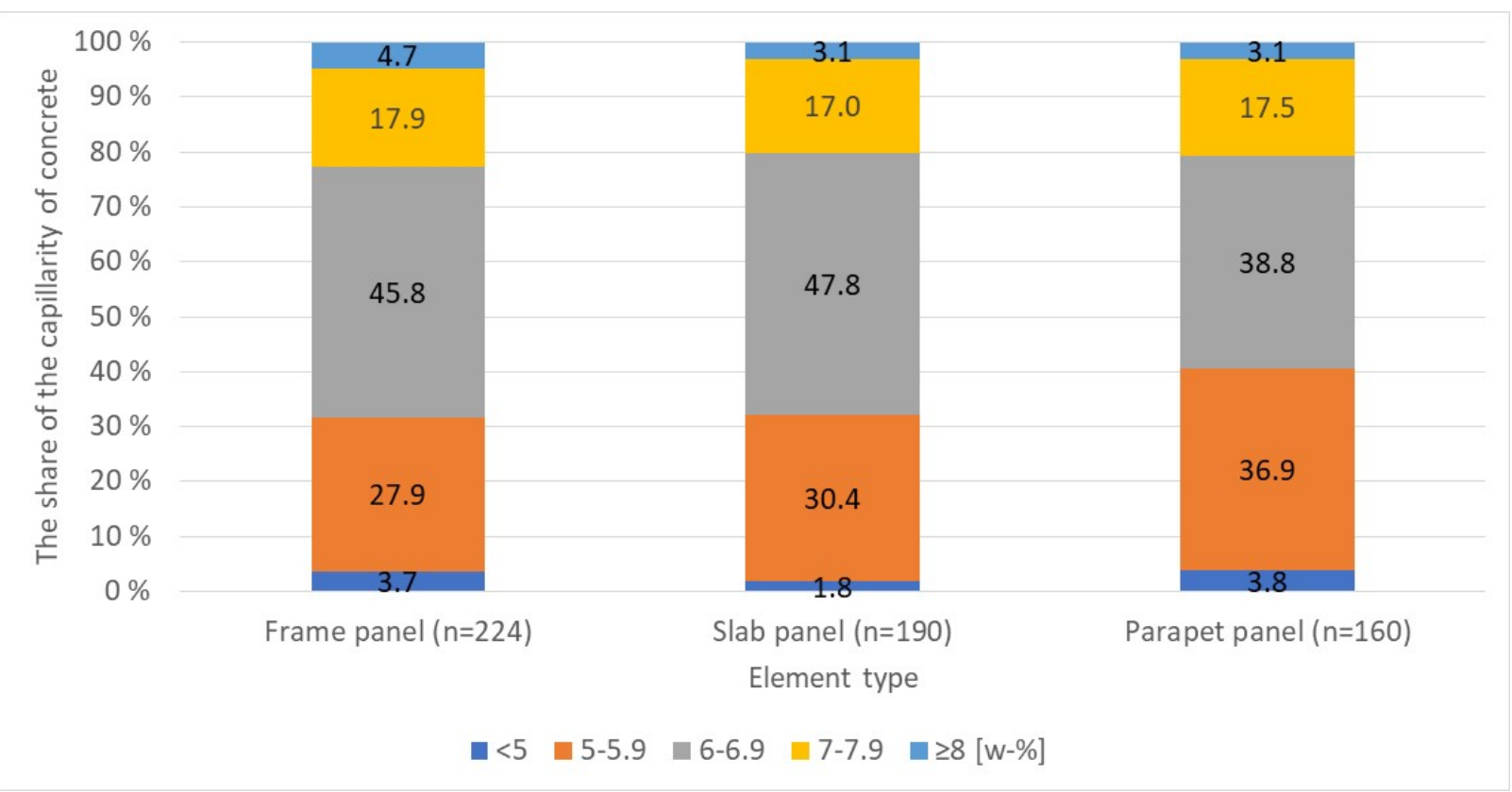

Figure 6-Capillarity of concrete in different precast balcony element types.

The capillarity in frame and slab panels is $6-6.9 \mathrm{w}-\%$ in almost $50 \%$ of the samples. $38.8 \%$ of parapet panels have capillarity of $6-6.9 \mathrm{w}-\%$ and $36.9 \%$ of parapet panels have capillarity of 5$5.9 \mathrm{w}-\%$.

\section{Capillarity of concrete in facades}

As seen on Figure 7, the capillarity of concrete varies considerably between different surface types in façade panels. Brushed painted, exposed aggregate and white concrete facade panels' capillarity is $6-6.9 \mathrm{w}-\%$ on average. The capillarity of ceramic tile finishing concrete is $7-7.9 \mathrm{w}-\%$ and brick tile finishing concrete has capillarity $\geq 8 \mathrm{w}-\%$.

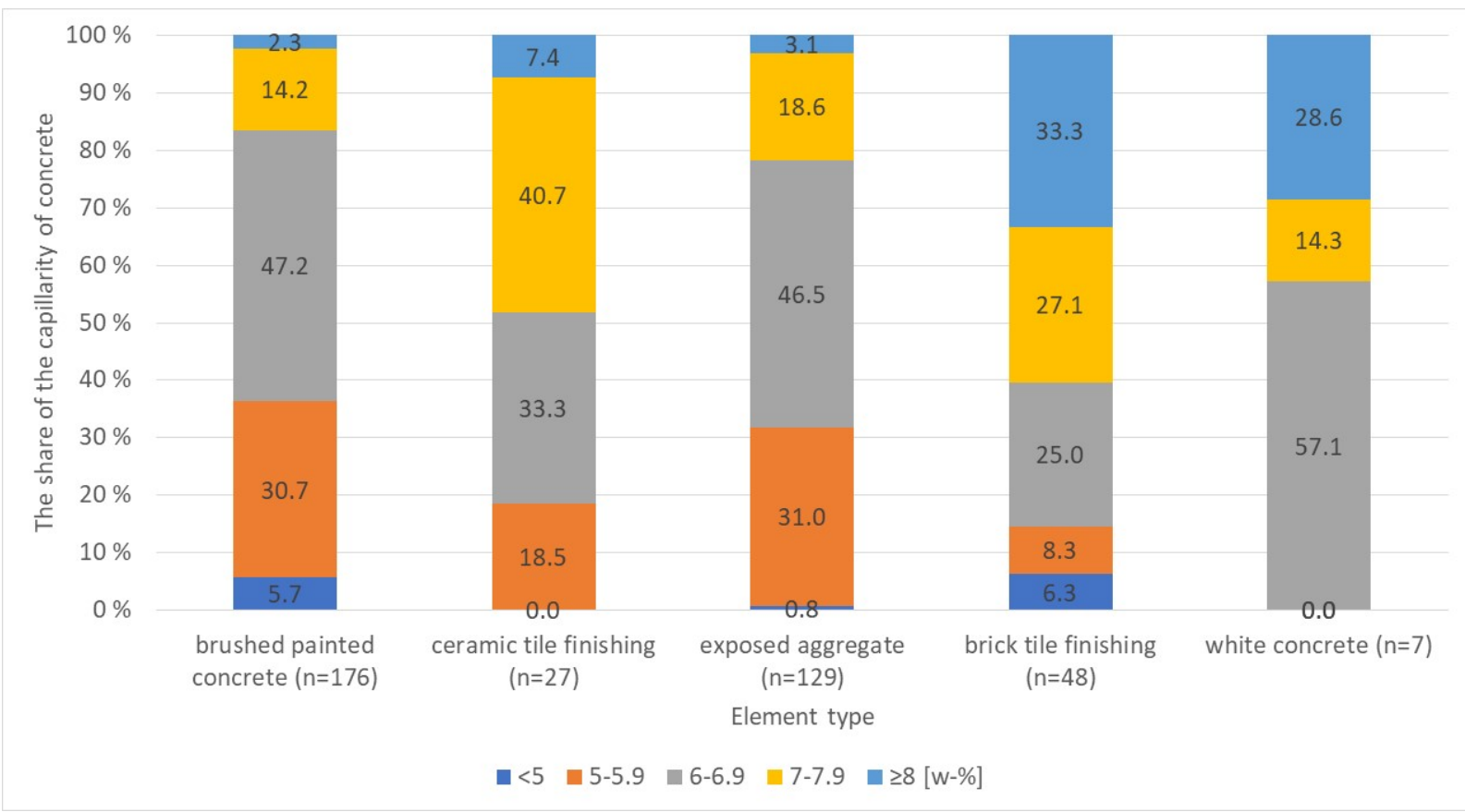

Figure 7 - Capillarity of concrete in different precast facade element types. 
The relation between capillarity and the carbonation coefficient in balconies

The relation between the capillarity of concrete and the carbonation coefficient was researched by fitting a line with the best correlation through the datapoints. The relation between capillarity and carbonation coefficient in frame panels is shown in Figure 8.

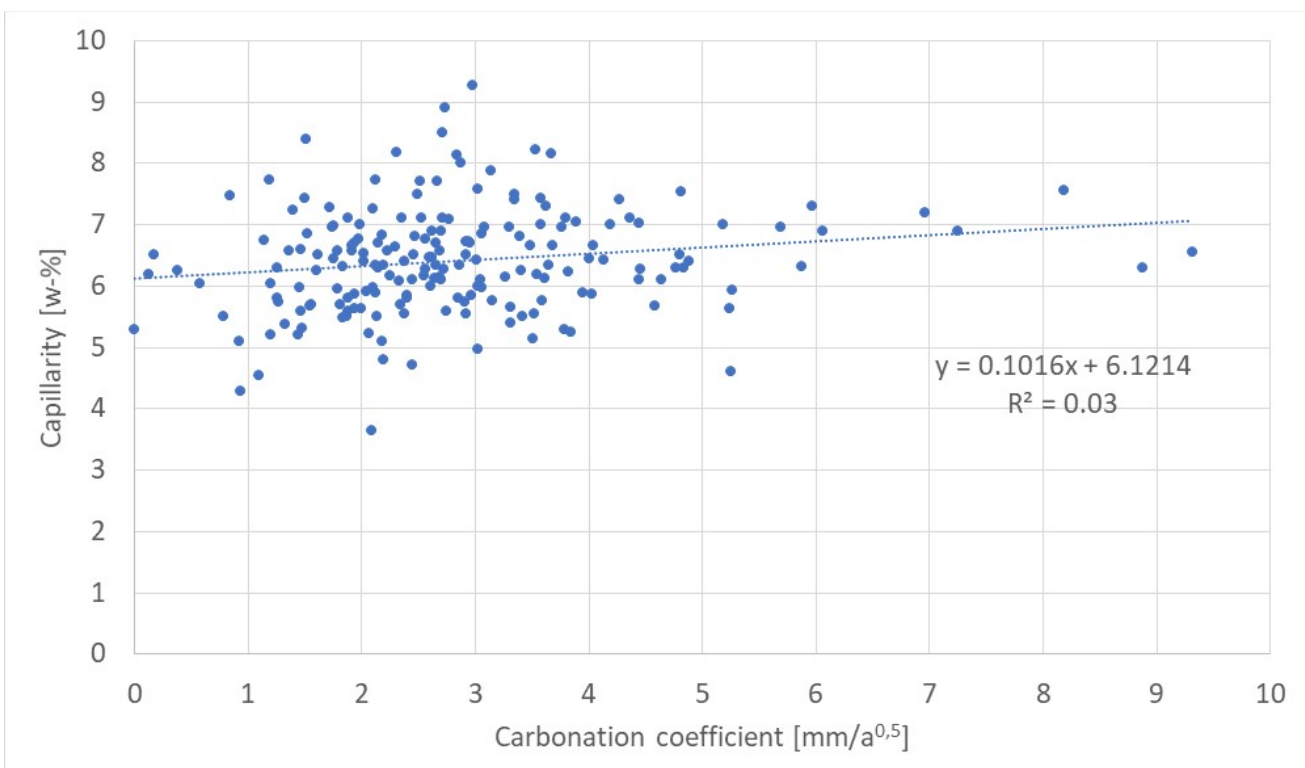

Figure 8 - Relation between capillarity of concrete and the carbonation coefficient in frame panels.

The average capillarity of concrete for precast balcony elements is $6-7 \mathrm{w}-\%$ while the carbonation coefficient varies between different element types. The carbonation coefficient is $1-3 \mathrm{~mm} / \mathrm{a}^{0,5}$ for parapet panels, $2-4 \mathrm{~mm} / \mathrm{a}^{0,5}$ for frame panels and $3-4 \mathrm{~mm} / \mathrm{a}^{0,5}$ for slab panels. The correlation coefficient $\mathrm{R}^{2}$ between capillarity and the carbonation coefficient is 0.03 for frame panels, 0.05 for the inner surface of parapet panels, 0.03 for the outer surface of frame panels and 0.02 for soffit of slab panels. In all cases the deviation of carbonation coefficient is high. Therefore, no correlation between capillarity and the carbonation coefficient can be seen. However, the carbonation coefficient of concrete increases slightly together with the capillarity of concrete.

The relation of capillarity and the carbonation coefficient in facades

The relation between capillarity of concrete and the carbonation coefficient in exposed aggregate facade panels is shown in Figure 9. 


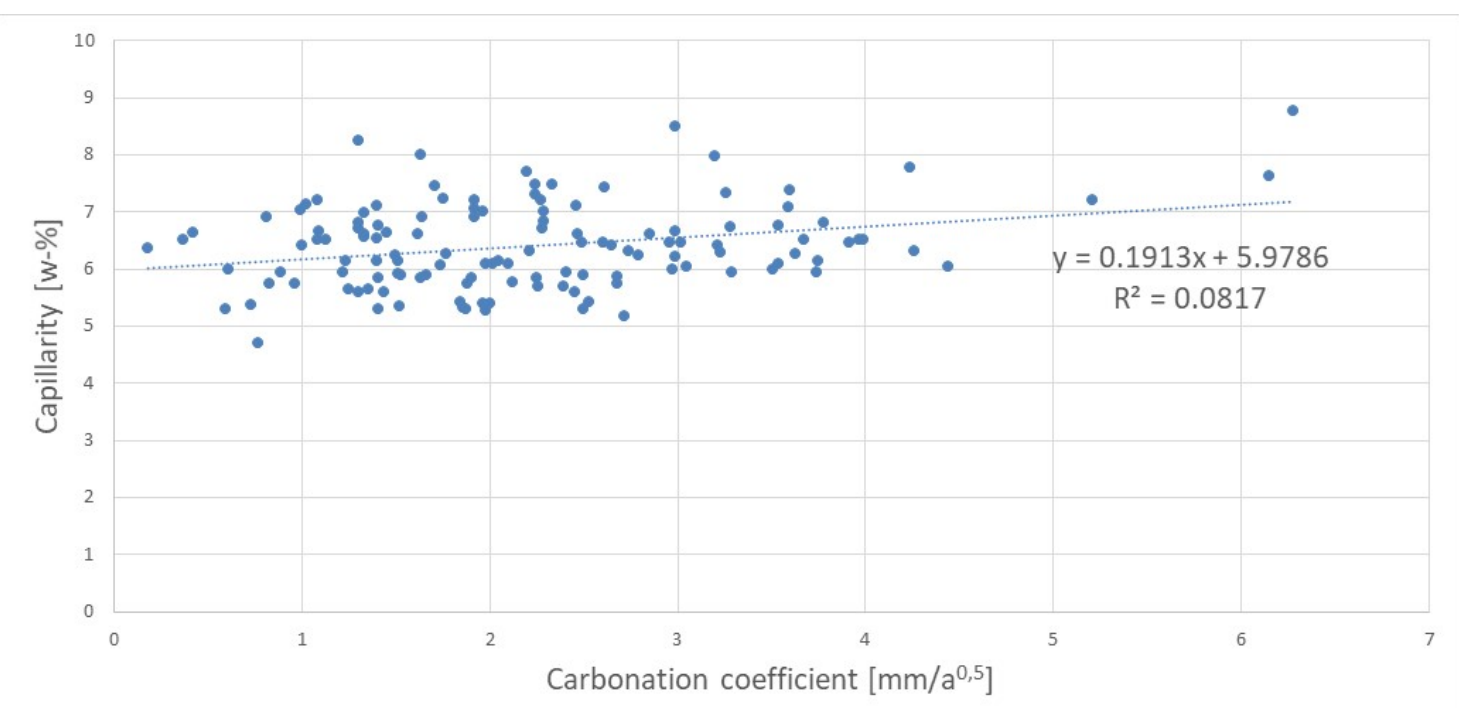

Figure 9 - Relation between capillarity and the carbonation coefficient in exposed aggregate facade panels.

The average capillarity of concrete for precast facade elements varies between the surface finishes (see Figure 7). The carbonation coefficient is $2-4 \mathrm{~mm} / \mathrm{a}^{0,5}$ for brushed painted panels, $<1 \mathrm{~mm} / \mathrm{a}^{0,5}$ for white concrete and $2 \mathrm{~mm} / \mathrm{a}^{0,5}$ for other finishes. The correlation coefficient $\mathrm{R}^{2}$ between capillarity of concrete and the carbonation coefficient is 0.08 for exposed aggregate facades, 0.00 for brushed painted facades, 0.00 for ceramic tile finishing facades, 0.01 for brick tile finishing facades and 0.23 for white concrete facades. Ceramic tile finishing, brick tile finishing, and white concrete facades have small sample sizes hence they have poor correlation coefficients. It can be stated that there is no correlation between capillarity and the carbonation coefficient because of high deviation of the carbonation coefficient.

\subsection{The concrete cover of reinforcement}

According to Finnish national design code BY68 [16], the minimum cover depth of concrete in exposure classes XC3 and XC4 should be $25 \mathrm{~mm}$ with the lifespan of 50 years and $30 \mathrm{~mm}$ with a lifespan of 100 years. The actual distribution of cover depths is shown in Table 5 for balcony elements and in Table 6 for facade elements.

Table 5 - The share of reinforcement cover depths [\%] in studied balcony elements.

\begin{tabular}{cccccccccccc}
\hline Element & $0-4$ & $5-9$ & $10-14$ & $15-19$ & $20-24$ & $25-29$ & $30-34$ & $35-39$ & $40-44$ & $45-49$ & $\geq 50$ \\
\hline frame & 0.1 & 3.6 & 5.4 & 14.3 & 18.1 & 16.2 & 16.7 & 10.4 & 6.8 & 4.1 & 4.7 \\
slab & 0.0 & 3.7 & 5.8 & 14.3 & 18.9 & 17.6 & 17.1 & 10.0 & 6.6 & 3.7 & 2,3 \\
parapet, & 0.0 & 2.0 & 3.8 & 10.9 & 15.9 & 17.3 & 20.1 & 13.9 & 8.8 & 4.0 & 3.1 \\
$\begin{array}{c}\text { outer } \\
\text { surface } \\
\text { parapet, } \\
\text { inner } \\
\text { surface }\end{array}$ & 0.2 & 6.7 & 9.1 & 19.2 & 20.3 & 14.4 & 13.6 & 7.4 & 4.5 & 2.5 & 2.2 \\
\hline
\end{tabular}

Every precast balcony element has reinforcement less than $25 \mathrm{~mm}$ depth from the surface. With the lifespan of 50 years, the minimum cover depth is not reached in $43 \%$ of all researched element types on average. With the lifespan of 100 years, the minimum cover depth is not reached in 60 $\%$ of the cases. 
Table 6-The share of reinforcement cover depths [\%] in studied facade elements.

\begin{tabular}{|c|c|c|c|c|c|c|c|c|c|c|c|}
\hline \multirow[t]{2}{*}{ Element } & \multicolumn{11}{|c|}{ Cover depth [mm] } \\
\hline & $0-4$ & $5-9$ & $10-14$ & $15-19$ & $20-24$ & $25-29$ & $30-34$ & $35-39$ & $40-44$ & $45-49$ & $\geq 50$ \\
\hline $\begin{array}{l}\text { brushed } \\
\text { painted, } \\
\text { mesh }\end{array}$ & 0.0 & 0.5 & 1.8 & 7.3 & 15.8 & 20.3 & 25.2 & 16.1 & 8.1 & 3.8 & 1.6 \\
\hline edge bar & 0.0 & 1.0 & 2.3 & 7.7 & 13.6 & 17.8 & 21.9 & 15.5 & 10.8 & 5.3 & 4.4 \\
\hline $\begin{array}{l}\text { clinker, } \\
\text { mesh }\end{array}$ & 0.0 & 1.8 & 5.3 & 17.4 & 21.5 & 19.7 & 20.7 & 8.7 & 3.6 & 1.2 & 0.5 \\
\hline edge bar & 0.0 & 4.5 & 5.9 & 19.1 & 25.1 & 16.1 & 15.7 & 9.1 & 3.2 & 1.2 & 1.0 \\
\hline $\begin{array}{c}\text { exposed } \\
\text { aggregate, } \\
\text { mesh }\end{array}$ & 0.0 & 0.4 & 2.9 & 10.4 & 21.6 & 25.5 & 23.0 & 10.2 & 4.3 & 1.7 & 0.6 \\
\hline edge bar & 0.0 & 0.4 & 1.4 & 6.0 & 15.4 & 23.2 & 26.9 & 14.7 & 7.7 & 3.1 & 2.1 \\
\hline $\begin{array}{c}\text { brick tile, } \\
\text { mesh }\end{array}$ & 1.7 & 7.0 & 5.6 & 4.4 & 5.0 & 5.5 & 11.9 & 18.9 & 20.2 & 13.3 & 7.3 \\
\hline edge bar & 0.1 & 4.2 & 5.5 & 4.3 & 2.0 & 2.6 & 7.7 & 14.6 & 20.5 & 16.1 & 22.4 \\
\hline $\begin{array}{c}\text { white } \\
\text { concrete, } \\
\text { mesh }\end{array}$ & 0.0 & 0.1 & 1.5 & 8.8 & 17.8 & 25.8 & 21.5 & 15.0 & 6.1 & 1.9 & 1.5 \\
\hline edge bar & 0.0 & 0.0 & 1.5 & 13.2 & 18.8 & 20.8 & 20.6 & 10.8 & 6.6 & 5.0 & 2.5 \\
\hline
\end{tabular}

Present requirements for minimum cover depth of reinforcement are not fulfilled in any of the facade panels. From 28.2 to 46.0 per cent of mesh reinforcement, the cover depth is less than 25 $\mathrm{mm}$ and from 16.1 to 54.6 per cent of edge bars, the cover depth is less than $25 \mathrm{~mm}$. The smallest cover depths are in clinker clad facades. Requirements for minimum concrete cover has varied between $10 \mathrm{~mm}$ and $25 \mathrm{~mm}$ from the 1960's to 1980's. High deviation of cover depths in general shows lack of quality control during manufacturing of elements. Relatively high proportion of cover depths are less than $10 \mathrm{~mm}$, which is usually critical for using patch repair.

The share of all reinforcement that lies in carbonated concrete is shown in Table 7 for balcony elements and in Table 8 for facade elements. Relatively large share of all reinforcement lies in carbonated concrete in all balcony structures, e.g. $21.8 \%$ in balcony slab soffits. Balconies are bearing structures and, therefore, widespread and far advanced corrosion damage may effect the bearing capacity of the structure. However, balcony soffit is sheltered from rain, and corrosion rate may not be so fast as in e.g., parapet outer layer.

Table 7 - The share of reinforcement in carbonated concrete in studied balcony elements

\begin{tabular}{lllll}
\hline & frame & slab soffit & $\begin{array}{c}\text { Element } \\
\text { parapet, outer } \\
\text { surface }\end{array}$ & $\begin{array}{l}\text { parapet, inner } \\
\text { surface }\end{array}$ \\
\hline $\begin{array}{l}\text { Average carbonation } \\
\text { depth [mm] }\end{array}$ & 14.0 & 15.1 & 10.9 & 10.9 \\
$\begin{array}{l}\text { Share of } \\
\text { reinforcement in } \\
\text { carbonated concrete }\end{array}$ & 18.1 & 21.8 & 8.4 & 18.1 \\
[\%] & & & \\
\hline
\end{tabular}


Table 8 - The share of reinforcement in carbonated concrete in studied facade elements

\begin{tabular}{|c|c|c|c|c|c|}
\hline & & & ment & & \\
\hline & $\begin{array}{l}\text { brushed, } \\
\text { painted }\end{array}$ & clinker clad & $\begin{array}{l}\text { exposed } \\
\text { aggregate }\end{array}$ & brick tile & white concrete \\
\hline $\begin{array}{l}\text { Average } \\
\text { carbonation depth } \\
{[\mathrm{mm}]}\end{array}$ & 13.7 & 3.4 & 10.3 & 6.8 & 1.6 \\
\hline $\begin{array}{l}\text { Share of mesh } \\
\text { reinforcement in } \\
\text { carbonated } \\
\text { concrete [\%] }\end{array}$ & 5.2 & 3.8 & 4.4 & 6.0 & 0.0 \\
\hline $\begin{array}{l}\text { Share of edge bar } \\
\text { reinforcement in } \\
\text { carbonated } \\
\text { concrete }[\%]\end{array}$ & 7.8 & 3.3 & 4.0 & 1.6 & 0.0 \\
\hline
\end{tabular}

In facades the share of reinforcement in carbonated concrete is much less than in balconies. Brushed painted concrete and exposed aggregate concrete facades have the largest share of reinforcement in carbonated concrete. Especially edge bars are potentially affecting visual corrosion damage because their bigger diameter compared to mesh.

\section{3}

\section{Visible corrosion damage}

\section{Balconies}

Corrosion damage has been divided into three groups: no damage, local damage and widespread damage. The amount of corrosion damage on different balcony element types is standardized in Figure 10.

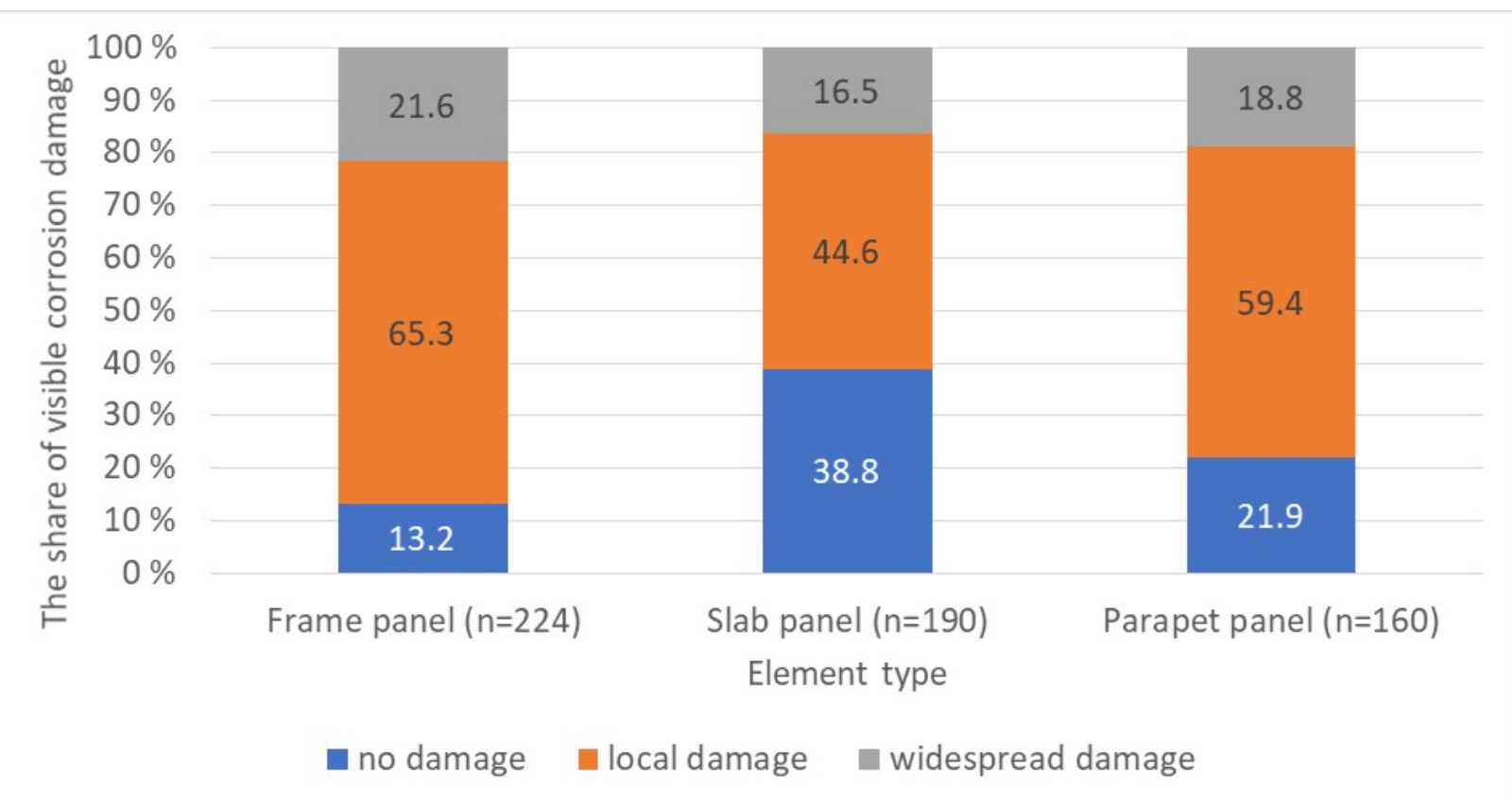

Figure 10 - The standardized amount of corrosion damage in different balcony element types.

As seen on Figure 10, visible corrosion damage is detected most in frame panels. Slab panels have relatively less corrosion damage compared to other element types. This occurs because the soffit 
of the slabs is covered from direct rain, while frame panels and the outsides of parapet panels are exposed to wind-driven rain (WDR).

\section{Facades}

The amount of corrosion damage on different facade element types is standardized in Figure 11.

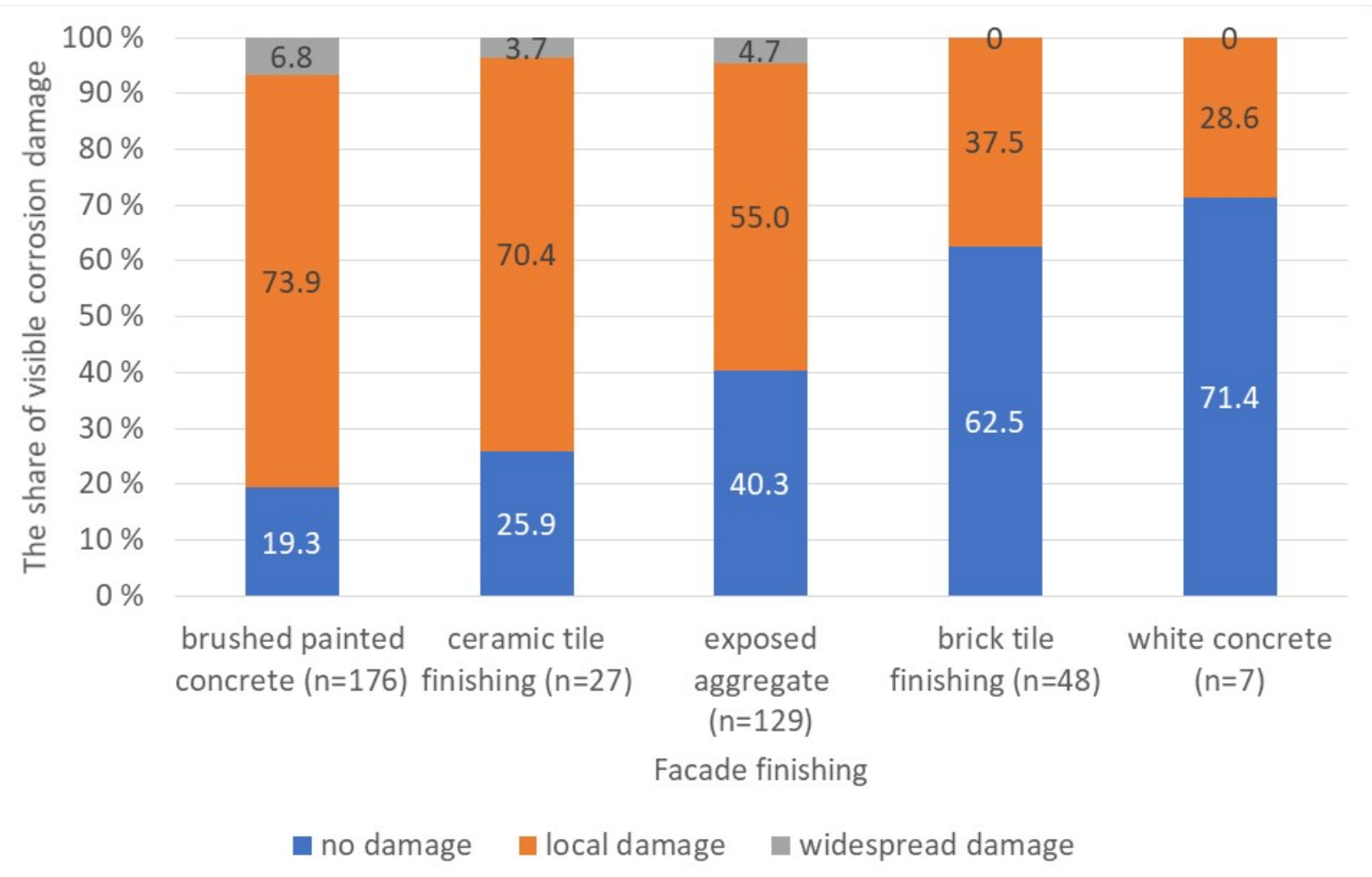

Figure 11 - The standardized amount of corrosion damage in different façade element types.

As seen on Figure 11, the amount of visible corrosion damage decreases while going right in the picture. Visible corrosion damage has been detected the most in brushed painted facades. The amount of fully damaged reinforcement is impalpable compared to balcony elements.

The relation of carbonation depth and visible corrosion damage in balconies

In Figure 12 is the amount of visible corrosion damage on different carbonation depths measured from the soffit of slab panels. Other balcony panels' corrosion damage in different carbonation depths imitates the distribution shown in Figure 12. 
Nordic Concrete Research - Publ. No. NCR 65 - ISSUE 2 / 2021 - Article 7, pp. 129-148

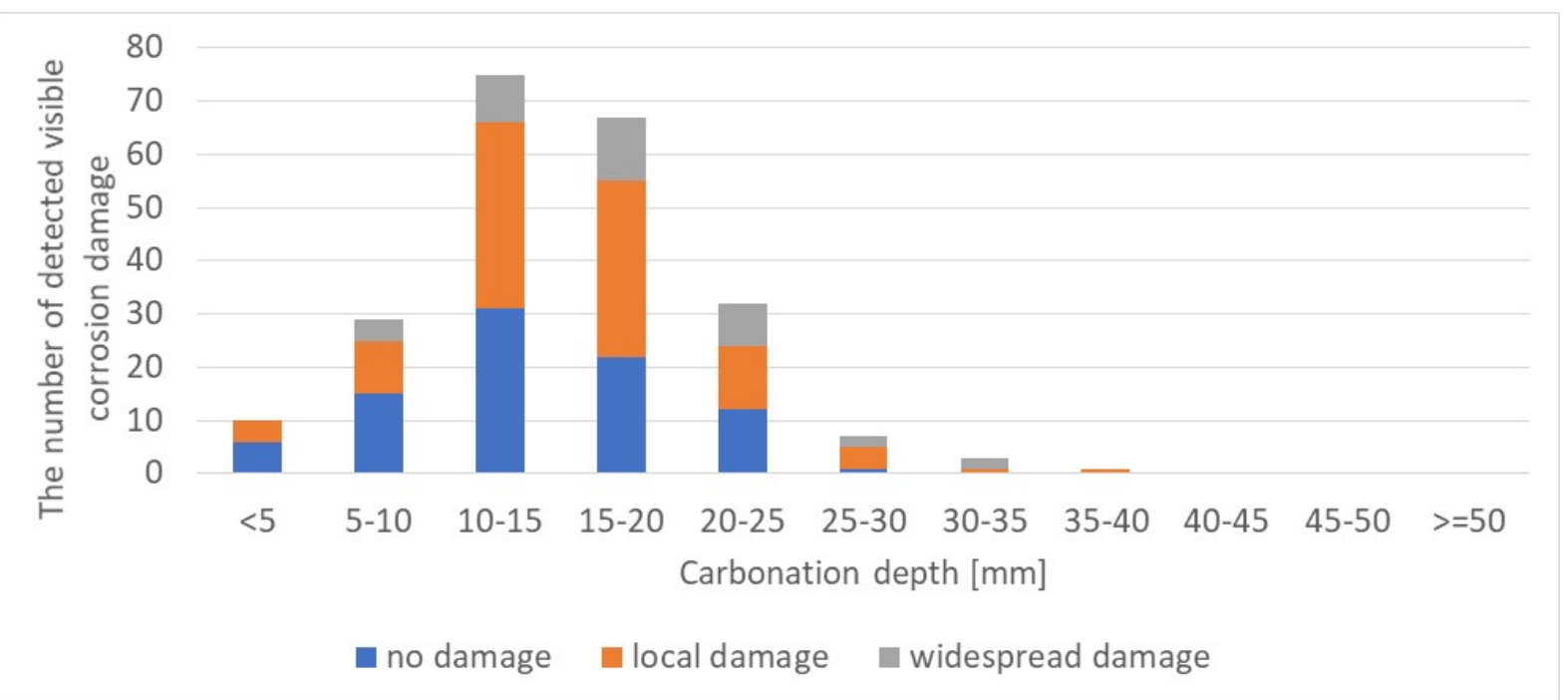

Figure 12 - Amount of visible corrosion damage in different carbonation depths measured from the soffit of slab panels.

The carbonation has proceeded mostly to $10-15 \mathrm{~mm}$ from the soffit of the slab panels. The time that passes before the carbonation depth of $10 \mathrm{~mm}$ is reached, can be estimated by comparing Figure 12 to Figure 4. Frame elements reach the carbonation depth of $10 \mathrm{~mm}$ in 11 years, slabs in 14 years and parapets in 21 years. The carbonation depth of $15 \mathrm{~mm}$ is reached in 24 years for frame panels, 29 years for slabs and 46 years for parapet panels.

The relation of carbonation depth and corrosion damage in facades

Figure 13 shows the amount of detected corrosion damage on different carbonation depths in brushed painted facade panels.

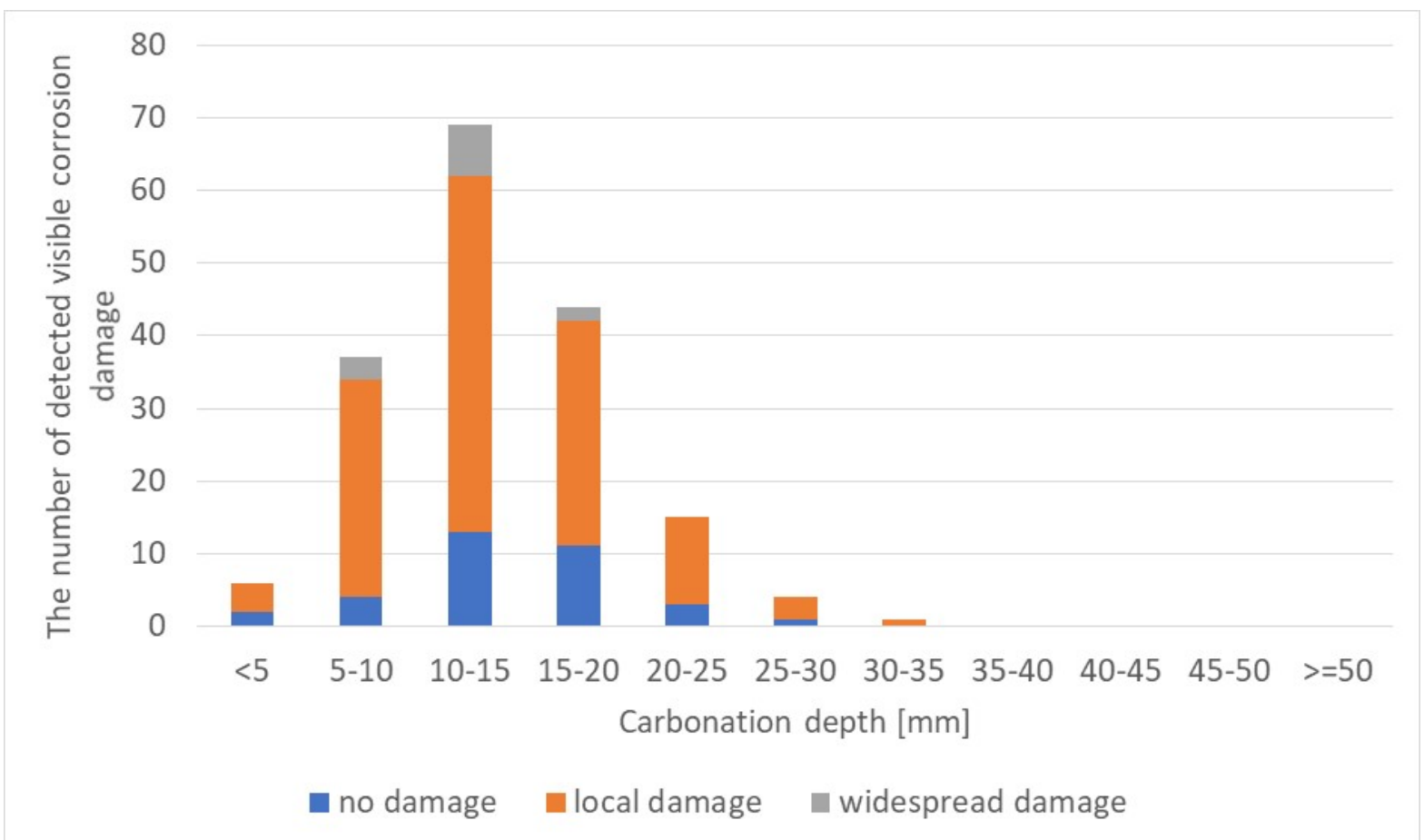

Figure 13 - Amount of visible corrosion damage in different carbonation depths on brushed painted facade panels. 
Like balconies, brushed painted facade panels have a carbonation depth of 10-15 $\mathrm{mm}$ on average measured from the outside of the facade. By comparing Figures 13 and 5, the carbonation depth of $10 \mathrm{~mm}$ is reached in 14 years and $15 \mathrm{~mm}$ in 32 years. In Figure 14 is the amount of detected visible corrosion damage in exposed aggregate facade elements.

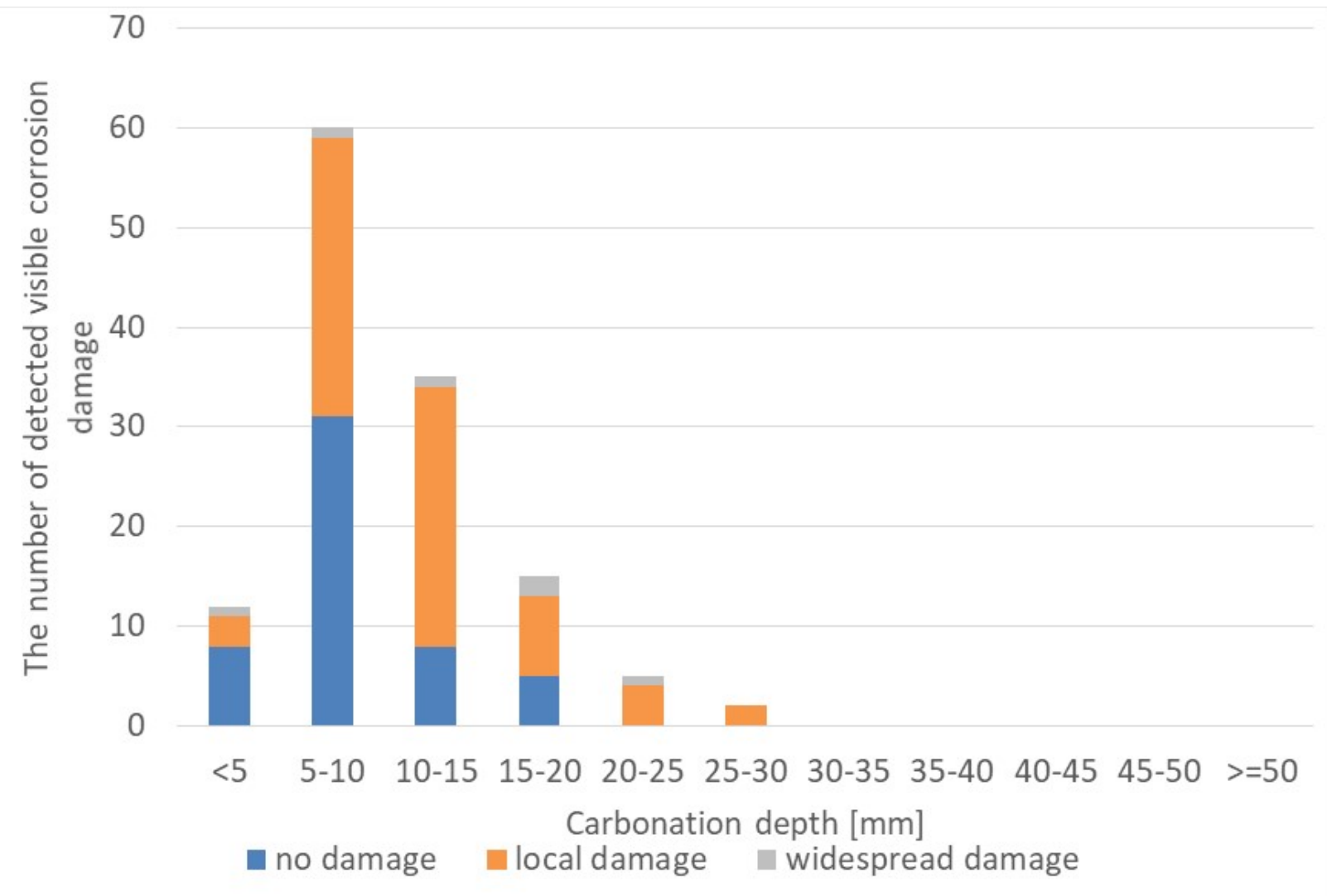

Figure 14 - Amount of visible corrosion damage in different carbonation depths in exposed aggregate concrete facade panels.

As seen on Figure 14, the carbonation of concrete has proceeded to the depth of $5-10 \mathrm{~mm}$ in exposed aggregate facade panels. The carbonation depth of $5 \mathrm{~mm}$ is reached already in 6 years and $10 \mathrm{~mm}$ in 21 years.

5.

\section{CONCLUSIONS}

Carbonation of concrete varies a lot depending on the facade type and balcony element. After 50 years carbonation has achieved 0 to $7.8 \%$ of reinforcement in facades and 8.4 to $21.8 \%$ of reinforcement in balconies. While capillarity of concrete increases, the carbonation rate increases respectively, but no correlation can be seen. Both capillarity of concrete and the carbonation rate detected great variation.

Most of the detected visible corrosion damage in the research data was local damage. Far advanced corrosion damage was detected more from balcony structures than facades. This was an expected result because more reinforcement lies in carbonated concrete in balcony structures than in facades. However, 13.2 to $38.8 \%$ of balcony elements and 19.3 to $62.5 \%$ of facade elements did not show visible corrosion damage despite reinforcement lied in carbonated concrete. 
According to the data $80 \%$ of structures will achieve longer service life than Finnish national design guideline presumes, because carbonation rate in real buildings is much slower than what the guideline presents.

\section{REFERENCES}

1. Finnish Concrete Industry ry: "Cement and greenhouse gas emissions" ("Sementti ja kasvihuonekaasupäästöt"), Read 5.4.2021. Available: https://betoni.com/tietoabetonista/perustietopaketti/betoni-rakennusmateriaalina/sementti-seosaineiden-kaytto/, (In Finnish).

2. Finnsementti oy: "Environmental report 2020" ("Ympäristöraportti 2020", Parainen, 2020, 30 p. (In Finnish).

3. Hewlett P \& Liska M: "Lea's Chemistry of Cement and Concrete". 5th Edition. Butterworth-Heiemann, 2019, 896 pp.

4. Lahdensivu J: "Durability Properties and Actual Deterioration of Finnish Concrete Façades and Balconies". TUT Publication No. 1028 ( $\mathrm{PhD}$ thesis), Tampere University of Technology, Finland, 2012, 117 pp.

5. Angst U, Moro F, Geiker M. Kessler S, Beushausen H, Andrade C, Lahdensivu J, Köliö A, Imamoto K, von Greve-Dierfeld S \& Serdar M: "Corrosion of steel in carbonated concrete: mechanisms, practical experience, and research priorities - a critical review by RILEM TC 281-CCC”. RILEM Technical Letters Vol. 50, 2020, pp. 85-100.

6. Tuutti K: "Corrosion of steel in concrete". CBI Research, No. 4, Swedish Cement and Concrete Research Institute, Stockholm, Sweden, 1982, 304 p.

7. Bakker R: 1988. "Initiation period", Chapter 3, "Corrosion of steel in concrete". (Edited by P. Schiessl). Chapman and Hall, London, UK, 1988, pp. 22-55.

8. Gjørv OE: "Durability design of concrete structures in severe environments". Taylor \& Francis, 2009, 220 p.

9. Parrott LJ: "A review of carbonation in reinforced concrete". Cement and Concrete Association, Slough, UK, 1987, 67 p.

10. Broomfield J: "Corrosion of steel in concrete". Oxon, Taylor \& Francis, $2^{\text {nd }}$ ed., 2007, 277 pp.

11. Köliö A: "Propagation of Carbonation Induced Reinforcement Corrosion in Existing Cocrete Facades Exposed to the Finnish Climate". TUT Publication No. 1399 (PhD thesis), Tampere University of Technology, Finland, 2016, 61 pp.

12. Hunkeler F: "Basics of corrosion and potential measurement in reinforced concrete structures". ("Grundlagen der Korrosion und der Potentialmessung bei Stahlbetonbauwerken“). FA 86/90, Bericht VSS No 510, Eidgenössisches Verkehrs- und Energiewirtschaftsdepartement, Bundesamt für Strassenbau, Schweizerische Gesellschaft für Korrosionsschutz, Zürich, Switzerland, 1994, 166 pp. (In German).

13. Hunkeler F: "Requirements for the carbonation resistance of concrete" ("Anforderungen an den Karbonatisierungswiderstanden von Betonen”). FA 012, Bericht VSS No. 649, TFB AG - Technik und Forschung im Betonbau, Wildegg, Switzerland, 2008, 191 pp. (In German).

14. Pentti M, Mattila J \& Wahlman J: "Repair of concrete facades and balconies. Part 1: Structures, degradation and condition investigation". ("Julkisivujen parvekkeiden korjaaminen. Osa 1: rakenteet, vaurioituminen ja kunnon tutkiminen”). Publication No. 87, Tampere University of Technology, Structural Engineering, Tampere, Finland, 1998, 156 pp. (In Finnish). 
15. Finnish Concrete Association: "Concrete Codes - by65". Helsinki, Finland, 2016, 150 pp.

16. Finnish Concrete Association: "Selection of concrete and service life design: guideline for desigders - by68". ("Betonin valinta ja käyttöikäsuunnittelu: opas suunnittelijoille"). Helsinki, Finland, 2016, 95 pp. (In Finnish)

17. Lahdensivu J, Varjonen S \& Köliö A: "Repair strategies of concrete facades" ("Betonijulkisivujen korjausstrategiat"). Publication No. 148, Tampere University of Technology, Structural Engineering, Tampere, Finland, 2010, 77 pp. (In Finnish)

18. Pakkala T: "Assessment of the climate change effects on Finnish concrete facades and balconies”. TAU Publication No. 204 (PhD thesis), Tampere University, Tampere, Finland, 2020, $98 \mathrm{pp}$. 